\title{
DETERMINANTS OF THE TEACHER'S PERCEPTION OF STUDENTS AT THE PRIMARY AND SECONDARY SCHOOL LEVEL
}

\author{
MAGDALENA JAKUBCZAK-CHODŹKO
}

\begin{abstract}
Contemporary tasks and imposed requirements in the area of education are focused on improving the efficiency and quality of teaching, including counteracting the disturbing phenomena of the "day of liquid modernity" [1, p. 15-29]. The teacher's person is perceived subjectively, from the perspective of the contractor of professional assumptions. The dynamics of educational processes and progressive civilization changes forces us to meet the emerging expectations of educational policy. The look of many leading educators, among others Jan Władysław Dawid, Zygmunt Mysłakowski, Wincenty Okoń, Maria Grzegorzewska, Czesław Banach for personality traits of the teacher has gone to oblivion to give way to schematic and mass teaching. Increasingly, attention is paid to how? and not who? teaches. Studies in the field of psychology and pedagogy pose a question; What should the teacher be like? Using the following article, in which I will base myself on empirical research, I want to answer a completely different aspect, what kind of teacher would the students want?
\end{abstract}

Keywords: authority, teacher, reflective features, practice, image.

\section{INTRODUCTION}

The teacher's personality, like the other components involved in the education process, is changing. This applies to the impact of social, cultural, self-realizing and intentional educational interactions. "Nobody had a ready personality. It is the result of specific, conducive processes of growth and upbringing, and above all self-education and continuous improvement. New educational strategies also require a new teacher". $[12$, p. 68]. The process of progress and constant changes in every area of life requires a look at the teacher's figure. This view can be based on a variety of perspectives. From the point of view of the teacher, students, parents, pedeutologists. But in my opinion, the most valuable opinions can be obtained from people without whom education would not make sense for existence, the most important ones - students.

In order to check what expectations pupils expect from the teacher at present, I conducted research among primary and secondary school students. Due to the limited volume of the text, in the article I will refer only to selected issues located in empirical research. The research I presented was conducted on a sample of 120 pupils from 12-20 years old, therefore primary and secondary school. The research was quantitative and the questionnaire was used as a tool. The questions were open, semi-open and closed, one-time and multiple-choice. 


\section{REFLECTIONS ON THE TEACHER'S MODEL}

In Socrates' time, self-knowledge and self-discovery were an important component of human experience. These determinants remain valid, especially in reference to the teacher's work [5]. The selfknowledge consists of m.in. a set of judgments, ideas about one's own appearance, intellect, character, social relations, attitudes, beliefs about which an individual should have clarity. Often the attitudes of the teacher towards the student, the teaching process and also towards the person are unconscious [4, p. 100-101]. The teaching profession has certain moral and ethical determinants that must be followed. They result from the accepted teaching ethics and consist of norms, attitudes and behaviors that are not defined [6, p. 29-31].

The teachers' attitudes awaited by the students include those that simultaneously confirm the validity of the views of the pedagogy representatives describing the necessary characteristics of the teacher's image: J.W. Dawid [3], Z. Mysłakowski [8], but also those that have not yet been considered as desirable. I will recall each of the features that were mentioned and marked most often.

Features related to personality and referring to ethics: principles of justice, conscientiousness and diligence, knowledge, sympathy shown to students, understanding and lack of bias.

Among the answers given in the question about the characteristics of an ideal teacher, as well as guidelines for a teacher who would like to become a student authority, a feature such as a sense of humor or having "good" contact with a student appeared very often. Many respondents said they appreciate the teacher's appearance. As the most important feature that should be mentioned, they mention: "fashionable outfit", "physical attractiveness", "well-groomed figure", "personal hygiene". The above answers may indicate changes in socio-cultural conditions that take place throughout Europe. They are most visible in the area of communication: (where the indirect form has become dominant, with the help of electronic tools), its quality, universality, the multiplicity of sources, the speed of information transmission. You can also talk about the correlation of the acceleration of information flow, along with the acceleration of the pace of life. And also the financial crisis, and thus the increase in unemployment. All these changes significantly influenced changes in the hierarchy of values and their transformation [6]. As a result, what appeared to be a completely new aspect of the assessment, which is the external appearance.

Other exhibited features are: arousing the interest of the student and an interesting way to conduct lessons that they treat equally with understanding and help in solving problems. It is worth citing those students' answers that refer to the interpersonal competence of the teacher and ethical attitudes:

"- observes the rules,

- does not ignore students,

- can appreciate the students' efforts,

- he explains, and does not ask to read in the textbook,

- understands that each student is different and has different options

- is a model of culture and punctuality."

The abovementioned indications can be considered in two ways in the didactic aspect of the teacher's work, on which he himself mainly focuses, during the setting up of the class scenario or from the point of view of the personality of the teacher. Both the first and the second way of interpretation will depend on the understanding of the designated features that can be implemented or considered unfulfilled depending on the "imaginations" on each of them.

I will now turn to the next question, which in a way is confirmation of the results contained in the previous question. The determinants that students follow in the assessment of their didactics are based on personality, openness to student problems and teacher's attitude to duties. Analyzing the individual responses, there is a difference in relation to some of them: the most important for students aged $18-20$ is openness to pupils' problems, while in the age of $12-14,15-17$ years the teacher's personality is the most important. 


\begin{tabular}{|c|c|c|c|c|c|c|}
\hline \multirow[b]{2}{*}{ No. } & \multirow[b]{2}{*}{ Determinants of teacher perception } & \multicolumn{3}{|c|}{ Age } & \multicolumn{2}{|c|}{ Total } \\
\hline & & $\begin{array}{c}12-14 \\
\text { years } \\
20^{*}\end{array}$ & $\begin{array}{c}15-17 \\
\text { years } \\
86^{*}\end{array}$ & $\begin{array}{c}18-20 \\
\text { years } \\
14^{*}\end{array}$ & $\begin{array}{l}\text { Ws } \\
120\end{array}$ & $\begin{array}{r}\% \\
100\end{array}$ \\
\hline 1. & Personality of the teacher & 17 & 72 & 11 & 100 & 83,3 \\
\hline 2. & Openness to students' problems & 16 & 63 & 14 & 93 & 77,5 \\
\hline 3. & Teacher's attitude to duties & 11 & 55 & 12 & 78 & 65,0 \\
\hline 4. & $\begin{array}{l}\text { The need for professional development } \\
\text { constantly implemented by him }\end{array}$ & 3 & 21 & 5 & 29 & 24,2 \\
\hline 5. & Younger teacher age & 1 & 18 & 0 & 19 & 15,9 \\
\hline 6. & Appearance & 1 & 7 & 0 & 8 & 6,7 \\
\hline 7. & Long work experience & 0 & 6 & 0 & 6 & 5,0 \\
\hline 8. & Short work experience & 1 & 1 & 0 & 2 & 1,7 \\
\hline 9. & Older teacher age & 0 & 2 & 0 & 2 & 1,7 \\
\hline
\end{tabular}

Tab. 1. Determinants student perception of the teacher. Source: own study.

The analysis of the data contained in the table allows to state that the didactic personality is more important in the opinion of students than its approach to teaching. Proven forbearance and empathy, also belong to the more desirable features than the attitude to duties.

The negative attitude towards the teacher changes the student's approach to the subject he is learning. $91 \%$ of respondents voted for this thesis. One of the determinants of the teacher's competence are interpersonal relations. The object of interpersonal skills is to create a friendly atmosphere and conditions conducive to development. Therefore, the influence of the educator on the pupil affects his approach to the subject. The above statements draw conclusions about the subject of the teacher from the perspective of the term used by Zygmunt Mysłakowski as having a "pedagogical talent" [12, p. 711]. Talent in the aforementioned meaning means having certain personality traits, among others; empathy, caring, openness and not specific didactic skills.

The next question in the research questionnaire concerned: the importance of the external appearance of the teacher for students. I am just mentioning the results obtained here. As it turns out only for $5 \%$ of respondents, it does not matter. For 38\% it is very important or important, and $57 \%$ describe it as indifferent. However, when analyzing Table 1 in the context of the next question, there is a clear discrepancy between the responses obtained. This means that the appearance significantly affects the image of the teacher, but it is not one of the main factors of perception by the students. As evidenced by the result of the sixth place in Tab. 1.

From among the questions that can significantly influence the approach of educators to their duties, I will mention the one that concerned the most desirable teacher personal qualities. Based on the obtained results, it can be concluded that the most desirable feature that a teacher should have is a sense of humor over $52 \%$, followed by justice for over $49 \%$ and forbearance for $43 \%$ of students.

The above conclusions should be treated as a description of a set of traits useful as a pedagogue from the perspective of students' opinions. According to Wincenty Okoń [8, p. 27-61], a good teacher should be creative, have knowledge about teaching and relationships between people. He describes three different perspectives of considering the traits held by the pedagogue.

The first one concerns the pedagogical abilities manifesting in relations with the student.

Second psychological abilities expressing in personal characteristics.

Third social ability containing social attitudes.

\footnotetext{
${ }^{*}$ - total number of respondents surveyed in a given age.
} 
Each of the three perspectives interacts with each other and corresponds with each other. Therefore, they should not be considered individually. The aspect of psychological skills is concerned with shaping the relationship with the student through a sense of humor, justice and understanding. Using the three personal characteristics listed above, the teacher builds a positive relationship with the student and therefore works also through the pedagogical perspective.

The research areas referred to refer to the use of the reflective teaching model [11]. Treating the role of reflection in professional development, in which the teacher, through reflection and awareness of the purpose of action, constantly monitors and evaluates events. And thanks to such actions he is able to improve his skills and strategies of conduct [2]. This applies to both didactic skills, which include practical activities as well as emotional attitudes belonging to motivational processes. The main obstacles to using a reflexive model based on self-assessment is the lack of knowledge about its importance for the learning process and the lack of information about what activities facilitate the support of education. Facing the above statements by analyzing the conducted research, I aimed at their reflective use by a group of pedagogues. Bearing in mind both their development as well as raising the quality of students' learning. "Reflective teachers become teacher-teachers who lead others, creating challenges for their students and organizing the educational environment" [10, p. 112].

\begin{tabular}{|c|l|c|c|}
\hline No. & \multicolumn{1}{|c|}{$\mathbf{X}$} & $\mathbf{W s}$ & $\mathbf{\%}$ \\
\hline 1. & Sense of humor & 63 & 52,5 \\
\hline 2. & Justice & 59 & 49,2 \\
\hline 3. & Indulgence & 52 & 43,3 \\
\hline 4. & Sympathy shown to the student & 41 & 34,2 \\
\hline 5. & Good manners & 23 & 19,2 \\
\hline 6. & Patience & 21 & 17,5 \\
\hline 7. & Tolerance & 14 & 11,7 \\
\hline 8. & Responsibility & 11 & 9,2 \\
\hline 9. & Cordiality & 11 & 9,2 \\
\hline 10. & Enthusiasm & 4 & 5,0 \\
\hline 11. & Parental instinct & 4 & 3,3 \\
\hline 12. & Firmness and consistency & 3 & 3,3 \\
\hline 13. & Tact & 1 & 2,5 \\
\hline 14. & Care & 0 & 0,8 \\
\hline 15. & other & \multicolumn{2}{|c|}{} \\
\hline
\end{tabular}

Tab. 2. The most desirable teacher's personal characteristics. Source: own study.

\section{CONCLUSIONS}

Building a teacher's image is a long and difficult process that requires a lot of effort and sacrifices, and also encourages the educator to constantly develop and expand his own competences. However, just as the teacher's work requires motivation, so building the image requires patience. Students' expectations are growing along with the changing world, technical progress and changes in education regulations. Bearing in mind the evolution of 21st century education, I focused on gathering information that would help dispel the doubts I have described which both the beginner and the experienced teacher are facing.

The research was aimed at determining the determinants of the teacher's perception, which significantly affect the students' learning and building its authority. From the analysis of data on how to interpret the concept of a teacher's image by students, one can draw a general conclusion that in the students' opinion it consists of personality, external appearance and authority in the eyes of students. The factor shaping the teacher's authority is openness to students' problems and needs. 
The analysis of the obtained research confirms the assumed hypotheses and leads to the conclusion that negative emotions, antipathy to the teacher are the result of changing the approach to the subject. The negative consequences are the drop in interest in the lesson and worse educational results. This attitude deprives pupils of enthusiasm for learning, discourages and blocks their activity. The views quoted above show that the effects of the work depend to a large extent on the extent to which the teacher is able to introduce a friendly attitude and empathy in his work with the students.

Success in teaching takes place when it is accompanied by full commitment and internal motivation, which arises from the interest to the acquired content and awareness of its usefulness.

Appropriate substantive, didactic and psychological-pedagogical preparation are key in the profession described, but they do not themselves make a person a teacher. The awareness of competences and tasks posed to future educators is extremely important. Not without significance is the self-esteem of self-worth, the level of knowledge and didactic-educational skills, high intelligence, as well as creative abilities.

To sum up the image of the teacher is one of the factors shaping his image, thanks to which he builds his authority and is also gifted with respect and trust. Respect for authentic authority can not be demanded of anybody, it can be given to pupils by the gifted ones. How the teacher will be perceived depends mainly on him. However, all the above-mentioned determinants make up the process of shaping the teacher's image, and thus the degree of students' interest in the lesson. Are the abovementioned elements of personality unattainable? No. How many teachers are aware of their relevance in the teaching process? Probably there are those who recognize No, all research questions and results have been quoted. Only those that seem the most interesting, changing the perception of the teacher's routine activities appeared. Probably everyone will use the above analysis in their own way. I hope that the issues raised in this article will inspire others to self-reflection and change thinking from objective, behavioral to subjective, humanistic.

\section{REFERENCES}

[1] Bauman Z. Wyzwania dla edukacji $\mathrm{w}$ dobie płynnej nowoczesności [Liquid modern challenges to education]. W: Siemieńska R. (Red.) Uniwersytety, Naukowcy i Studenci w Zglobalizowanym Świecie: Wybrane Zagadnienia [Universities, Scientists and Students in a Globalized World]. Scholar, Warszawa, 2017, 15-29. (in Polish)

[2] Brzezińska A. Refleksja w działalności nauczyciela [Reflection in teacher's activity]. Studia Edukacyjne, 3 (1997), 113-133. (in Polish)

[3] Dawid J.W. O Duszy Nauczycielstwa [On the Soul of Teachers]. Nasza Księgarnia, Warszawa, 1946. (in Polish)

[4] Kabzińska Ł. Aktualność rozważań o powinnościach nauczyciela i jego kompetencjach interpretacyjnych [The timeliness of considerations about teacher's duties and its interpretation competences]. W: Nowicka M. (Red.) Nauczyciel i Uczeń w Przestrzeniach Szkoły [Teacher and Student in the School Space]. UWM, Olsztyn, 2002. (in Polish)

[5] Kozielecki J. Psychologiczna Teoria Samowiedzy [Psychological Theory of Self-Knowledge]. PWN, Warszawa, 1986. (in Polish)

[6] Miszalska A. Reakcje Społeczne na Przemiany Ustrojowe: Postawy, Zachowania i Samopoczucie Polaków w Poczatkach Lat Dziewięćdziesiatych [Social Reactions to Political Changes]. Uniwersytet Łódzki, Łódź, 1996. (in Polish)

[7] Molesztak A., Tchorzewski A.M., Wołoszyn W. W Kregu Wartości Moralnych Nauczyciela [Within the Circle of Moral Values of the Teacher]. WSP TWP, Warszawa, 1996. (in Polish)

[8] Okoń W. Wprowadzenie do Dydaktyki Ogólnej [Introduction to General Didactics]. Żak, Warszawa, 1995. (in Polish) 
[9] Okoń W. Problemy osobowości nauczyciela. W: Okoń W. (Red.) Osobowość Nauczyciela. Rozprawy J.Wt. Dawida, Z. Mystakowskiego, St. Szumana, M. Kreutza, St. Baleya [Personality of the teacher. Dissertations J. Wt. Dawida, Z. Mystakowskiego, St. Szuman, M. Kreutz, St. Baley]. PZWS, Warszawa, 1959. (in Polish)

[10] Scott G. Paris, Linda R. Ayres. Stawanie Się Refleksyjnym Uczniem i Nauczycielem [Becoming a Reflective Student and Teacher]. WSiP, Warszawa, 1997. (in Polish)

[11] Schön D.A. Educating the Reflective Practitioner. Jossey-Bass, San Francisco, 1987.

[12] Suchodolski B. Pedagogika. Podręcznik dla Kandydatów na Nauczycieli [Pedagogika. Manual for Candidates for teachers]. PWN, Warszawa, 1982. (in Polish)

[13] Żebrowski J. Współczesny nauczyciel-wychowawca i jego świat wartości [Contemporary teachereducator and his world of values]. Studia Gdańskie, 4 (2007), 163-176. (in Polish)

Address: Magdalena Jakubczak-Chodźko, Institute of Pedagogy of the Jagiellonian University, 12, Batorego Str., Kraków, 31-135, Poland.

E-mail: jakubczakmagdalenaa@gmail.com

Received: 11.12.2018; revised: 15.01.2019.

Якубчак-Ходько Магдалена. Детермінанти сприйняття вчителя на рівні початкової та середньої школи. Журнал Прикарпатського університету імені Василя Стефаника, 6 (1) (2019), 37-42.

Сучасні завдання та вимоги, що висуваються у сфері освіти, спрямовані на підвищення ефективності та якості навчання [1, р. 15-29]. Сьогодні особистість учителя сприймається суб'єктивно. Динаміка освітніх процесів і прогресивних цивілізаційних змін змушуе нас відповідати очікуванням політики освітньої галузі. Погляди багатьох провідних педагогів на особистісні якості учителя, серед яких: Ян Владислав Давид, Зигмунт Мислаковський, Вікенті Оконь, Марія Гжегожевська, Чеслав Банах, давно відійшли у забуття, щоб поступитися місцем ідеям схематичного та масового навчання. Сьогодні все частіше постає питання: “Як?" а не “Хто?" навчає. Дослідники у галузі психології та педагогіки неодноразово ставдять такі питання: Яким повинен бути педагог сьогодення? У представленій статті автор демонструе резудьтати власного емпіричного дослідження, в якому проаналізовано дещо інший аспект питання: Якого вчителя / викладача хоче бачити сьогодні (учень) студент? У даному дослідженні визначено детермінанти сприйняття вчителя, які істотно впливають на процес навчання студентів. Проаналізувавши результати дослідження, автор дійшов загального висновку, що для учнів (студентів) вагомим у особистості вчителя є: зовнішній вигляд, авторитет, відкритість до проблем і потреб учнів.

Кдючові слова: авторитет, вчитель, рефлексивні ознаки, практика, педагогічний імідж. 